\title{
Public-data File 85-7
}

A REFRACTION PROEILE FROM HATCHER PASS TO SEWARD, SOUTH-CENTRAL ALASKA

\author{
By \\ J.N. Davies \\ Alaska Division of \\ Geological and Ceophysical Surveys
}

March 1985

THIS REPORT HAS NOT BEEN REVIEWED FOR TECHNICAL CONTENT (EXCEPT AS NOTED IN

TEXT) OR FOR CONEORMITY TO THE

EDITORIAL STANDARDS OF DGGS.

794 University Avenue, Basement

Falrbanks, Alaska 99701 
FINAL REPORT

to

THE DEPARTMENT OF TRANSPORTATION AND PUBLIC FACILITIES

for a profect entitled

A REFRACTION PROFILE FROM HATCHER YASS TO SEWARD, SOUTH CENTRAL ALASKA

\author{
by \\ Dr. John N. Davies \\ State Se1smolog1st \\ Alaska Division of Geological and Geophysical Surveys \\ and \\ Adfunct Assoclate Professor of Geophysics \\ Geophysical Institute \\ University of Alaska
}


EXECUTIVE SUMMARY................................

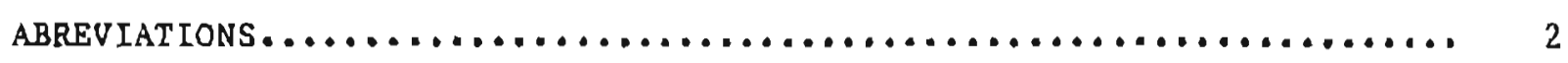

BACKGROUND..................................... 2

INSTALLATION OF TEMPORARY STATIONS..................... 3

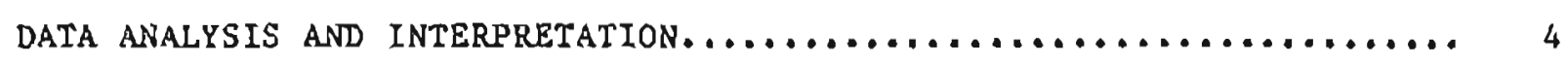

DISCUSSION..................................... 6

FUTURE WORK..................................... 7

CONCLUSIONS....................................... 8

ACXNOWLEDGEMENTS.................................... 9

TABLES......................................... 10

EIGURES ........................................ 14 
EXECUTIVE SUMMARY

Late in the Fall of 1982 Alaskan selsmologlsts became aware that large explosions were being detonated near Blrd Creek on Iurnagln Arm. These explosions were for the purpose of widening the Seward ylghway south of Anchorage. The largest of these explostons, about 33,000 1bs of TNT, could be seen on records made by the selsmograph at McKlnley Station, some $300 \mathrm{~km}$ distant from the blast sice. Also visible on the records of the many selsmographs around the Susicna and Matanuska Valleys and the Renal Peninsula were some distinct secondary arrivals. A careful analysis of these arrival times has given a good callbration of the velocitles of the crustal layers beneath the Matanuska Valley and the Kenal Peninsula. These veloctties are fundamental data required to more preclsely locate earthquakes in the region. By the elme we learned of the blasts only two large ones remalned; they were scheduled for October 19 and 26, 1982. A jolnt project was agreed upon by the following agencles:

1. U.S. Geological Survey, Menlo Park, CA

2. Geophysical Institute, UnIvers1ty of Alaska, Falrbanks

3. Division of Geological and Geophyical Surveys, Falrbanks

4. Alaska Tsunaml Warning Center, Palmer

5. Research Section, Division of Planning and Programs, DOT/PF, Falrbanks

The USGS deployed atations along the Seward Highway souch of the blast slce. The DGGS and the Geophysical Institute deployed Instruments to the north of the blagt site. The Tsunaml Warning Center provided logigric support, facilifles and apecial recording of the stations deployed by UAGI and DGGS. The Research Section provided financlal support to UAGI and 1lalson between the ocleatists in the fleld and the contractor at the blast site. 
About 16 temporary gtations were escablished, eight to the south and eight to the noxth of the blast site. Sharp and clear arrivals were recorded at about 10 of these stations as well as at several of the permanent stations. Preliminary results show that adjustments stould be made to the velocity model for the Kenal Peninsula and Matanuska Valley.

The velocity model derived here shows an upper layer about $2 \mathrm{~km}$ thick whth a P-wave velocity of $5.55 \mathrm{~km} / \mathrm{sec}$ in comparison to the value curtently in use of $2.75 \mathrm{~km} / \mathrm{sec}$; the second layer has a velocity of $6.22 \mathrm{~km} / \mathrm{sec}$ beginning at $2 \mathrm{~km}$ depth and extending to $15-20 \mathrm{~km}$ depth. P-wave veloctties used in other models for the area don't reach $6.2 \mathrm{~km} / \mathrm{sec}$ at depths shallower than $10 \mathrm{~km}$.

\title{
ABBREVIATIONS
}

The following abbrevlations are used throughout the report:

\author{
ATWC Alaska Tsunaml Warning Center, NOAA \\ DOT/FF Dept. of Transporcation and Public Faclifies, State of Alaska \\ UAGI University of Alaska, Geophysical Insticute \\ USGS United States Geological Survey \\ DGGS Division of Geological and Geophysical Surveys, State of Alaska.
}

\section{BACKGROUND}

During the late summer of 1982 personnel of the selsmology groups at the USGS in Menlo Park and at the Geophysical Institute in Falrbanka became aware that some rather large blasts were being set off in connection with a DOT/PF project to Improve the Seward Highwag in the vicinity of Bird Creek, on Turnagin Arm (gee Figure 1). Some of these blasts were large enough to be 
recorded by regional selomograph stations at distances up to $300 \mathrm{~km}$ from Bird Creek. It was agreed that some useful information about the structure of the crust could be obtalned by deploying some temporary selsmograph stations along a generally north-south allgnment from Hatcher Pass (HTP, Figure 1) to Seward. Further, a general division of responsibility was assigned whereby the USGS would Install stations from Bird Creek south to Seward and would record shot times, and a UAGI/DGGS group would install statione from Bird Creek north to Hatcher Pass. Below, we report only on the northern part of the project carried out by UAGI and DGGS personnel with Elnancial suport from DOT/PF and assistance from personnel at the ATWC.

\section{INSTALLATION OF TEMPORARY STATIONS}

Elght temporary stations were installed north of Blid creek. The locations of these stations are shown by the open trlangles in Figure 1 and thelt coordinates and other information related to chelr locations are given 10 Table 1. These were all standard UAGI short-period, vertcal-component telemetered selsinic stations. They consisted of Geotech S-13, $1 \mathrm{~Hz}$ selsmometers, Monitron amplifler-VCOs, and Monitron VuF transmitters.

S1gnals were recorded at the ATWC Observatory at Palmer. An unused USGS Develocorder (16 fim fim recorder) was pressed into service along with some of the1r spare Develco discriminators. The radio frequency signals were picked up at Palmer using UAGI Monitron recelvers. F1lm and record-changing were provided by ATHC.

The selsmte signals from the elght temporary stations were recorded along with slgnals from nine permanent, regtonal stations operated respectively by the USGS, ATWC and UAGI. The locations of the reglonal statlous are shown by the solid trlangles in Flgure $l$ and thelr coordinates and other information 
are given in Table 1. This combination of temporary and permenent stations was operaced for 14 days from October 15, 1982 through October 28.

\section{DATA ANALYSIS AND INTERPRETATION}

Three blasts were recorded, one on October 19 and two on October 26 . The orlgtn times, locations and sizes of these three events (nos, 5, 6 and 7) and four other blasts are given in Iable 2. The locacion of the blasts relarlve to the selsmic stations is shown in figrue 1 (note that on the scale of this figure the individual locations of the blasts are indistinguishable). The fllm records of the blasts were scaled on a Geotech film viewer just as if they had been earthquakes. The arrival times of distinctive phases were read to the nearest twentleth of a second. The arrival clmes were then corrected for the elevation of the station (above sea level) and converted to travel times from Bird Creek to the Individual stations by subtracting the orlgin t1me:

$$
T T=A T-C(E)-O T
$$

where TT 18 the corrected travel time, AT ls the raw arrival time, $C(E)$ is the elevation correction $(\mathrm{E}+5 \mathrm{~km} / \mathrm{sec})$ and $\mathrm{OT}$ is the origin time of the blast. The $C(E)$ are given In Table 1 for each stat1on; the or are given in Table 2 for each blast. The TT are sumbrized in Table 3 and are plotted against distance to the respective selswic station in figure 2 .

The simplest way to facerpret these data is to fit them to a model of the crustal structure which consists of $\mathrm{N}$ horlzontal layers. The travel time as $\mathrm{a}$ function of distance, $D$, for such a model is:

$$
T T_{1}=\frac{D}{V_{1+1}}+2 \sum_{j=1}^{1} \frac{B_{j} \cos \theta_{j}^{1}}{V_{j}}
$$


where $\mathrm{TT}_{1}$ is the cravel cime for the wave refracted along the bottom of the $1^{\text {th }}$ layer, $D$ is the distance from shot to station, $V_{1}$ is the p-wave velocity In the $1^{\text {th }}$ layer, $H_{j}$ is the chickness (km) of the $f^{\text {th }}$ layer and $\theta_{j}$ is the angle the ray path makes with the vertical in the $1^{\text {th }}$ layer for the ray botcoming fust below the $j^{\text {th }}$ layer. Therefore, the slope of a straight line In Figure 2 is $\frac{1}{V_{1+1}}$, so the 1nverse of the slope of the $1^{\text {th }}$ branch of the cravel time curve is the velocity of the $(1+1)$ st layer. And the corresponding Intercept of the $1^{\text {th }}$ branch is:

$$
I_{1}=2 \sum_{j}^{1} \frac{H_{j} \cos \theta_{j}^{1}}{v_{j}}
$$

which can be rewritten

$$
H_{j}=\frac{V_{1}}{\cos \theta_{1}^{1}}\left[\frac{I_{1}}{2}-\frac{1}{\sum_{1}} \frac{H_{1} \cos \theta_{1}^{I}}{V_{1}}\right]
$$

whlch can be solved lteratively for the layer thicknesses given the $V_{1}$ and $I_{1}$ from the varlous branches of the travel-time vs. distance plot such as is shown 1n Flgure 2.

In the present case we assume only one layer over a half space so we have fle two branches to the data: one for the direct arrival which travels oniy In the top layer and a second one for the refracted ray path which follows the top of the half space.

In Figure 2 the Ilne which goes through the orlgin and the open gymbols corresponds to the direct arrival. The goodsegs-of-fit measure, $r^{2}$, for this Iine 1s 0.998 . The 1nverse of the slope of this line gives a velocity of $5.55 \mathrm{~km} / \mathrm{sec}$ for the flrst layer. The line through the solld symbols corresponds to the refracted arrivals and has a goodness-of-fit measure of $r^{2}$ 
$=0.998$. This line has an inverse slope of $6.22 \mathrm{~km} / \mathrm{sec}$ and an intercept time of 0.30 sec. Using this incercept time and these two velocities $(5.55$ and 6.22) equation (4) gives $1.84 \mathrm{~km}$ for the thlckness of the layer. Summarlz1ng, we have a layer $1.84 \mathrm{~km}$ thlck with a velocity of $5.55 \mathrm{~km} / \mathrm{sec}$ which overlies a half space whth a velocity of $6.22 \mathrm{~km} / \mathrm{sec}$.

To check this model we can use equation (2) to calculate the expected travel times for the refracted ray to each of the selsulc stations in our experiment. Simplifying (2) we have:

$$
T T_{1}=\frac{D}{V_{2}}+2 \frac{\mathrm{H}_{1} \cos \theta_{1}}{V_{1}}
$$

where $D$ is the distance to the station, $V_{1}=5.55 \mathrm{~km} / \mathrm{sec}, V_{2}=6.22 \mathrm{~km} / \mathrm{sec}, \mathrm{H}_{1}$ $=1.84 \mathrm{~km}$ and $\theta_{1}^{1}=63.16 \mathrm{degrees}$ (from Snell's Law).

Using (5) the expected travel times, $\langle T T\rangle$, have been calculated and compared to the mean travel time, $\overline{\mathrm{TT}}$ for each station. This comparison is shown in Table 4. The standard deviation of the difference between the expected and observed travel times is 0.29 seconds, and the worst case is 0.61 seconds. Considering the simplictty of the model and the vartety of geologic settings for the varlous selswic stations this is quite a good fit between model and data.

\section{DISCUSSION}

While this is a reasonably good fit to the majorlty of the better quality data (1.e., those where a particular cravel time is seen at a station for two or three of the blasts), there are many arrivals which are not explained by this mode1, some of whtch are quite strong. In particular, note the 8.3 second travel time at $27.5 \mathrm{~km}$ (PMS). Thls was quite strong and seen at PMS for two of the blasts. If this arrival is interpreted as a reflection from the bottom of the $6.22 \mathrm{~km} / \mathrm{sec}$ layer it would suggest that this layer $1 \mathrm{~s}$ about $20 \mathrm{~km}$ thick. 
During the past summer the USGS shot a detalled refraction line from near Valdez to Paxson. One of the more 1nteresting features of this ine is a series of "en echelon" sets of arrival times which suggests that the crust is composed of alternating layers of high and low velocity. A 11ne fit to the more distant end of each of these sets has a slope which corresponds to a "velocity" of about $6.2 \mathrm{~km} / \mathrm{sec}$. These sets of arrivals are l1mited to stations grouped in $10-15 \mathrm{~km}$ intervals (the staion spacing for the USGS line was about $1-2 \mathrm{~km}$ ). This suggests that as a result of the sparce atation spacing of the present experiment (about $10-20 \mathrm{~km}$ ) the results may be spatlally allaged so that there is in fact no thlck layer with a velocity of $6.22 \mathrm{~kg} / \mathrm{sec}$.

However, the crustal model obtaloed here is still quice useful for locating earthquakes using sparce networks of selsmograph staclons. Further, 1f the secondary arrivals which don't fall on the two main branches in F1gure 2 (the simple error bars) do correspond to arrivals from a stack of high and low velocity layers, there 13 no obvious, unique, en echelon pattern to them. Therefore, the very simple model used here 19 probably the most epproprlate one, given the nature of the data from the present experiment.

\section{FUTURE WORK}

With respect to the data collected during this experiment, there are four remalning tasks which would be useful to complece:

(1) Incorporate the data from the USGS stations to the south of Bird Creek. It may be worthwhile to digitize the UAGI data since the USGS data were digitally recorded. This would make possible a more unfform approach to processing the data. 
(2) Refine and extend the velocity model. This would include an 1terative evaluation of the arrival time picks in IIght of the predicted arrival times from the model, in terms of both the times and the relative amplitudes of the vartous phases. It should be possible to read sore reflected phases to constrain the depth of the base of the $6.22 \mathrm{~km} / \mathrm{sec}$ layer. Consideration might be glven to any evidence for dipping layers.

(3) Read arrival times from other blasts at the reglonal stations of UAGI, ATWC and USGS. "Relocation" of the blasts as if they were earthquakes using the cruscal model derived in step (2) might shed light on station corrections for routine use in the location of earchquakes in the greater Anchorage area.

(4) Read arrival times from earthquakes in the Macauuska Valley during the period October 14-28 when the UAGI temporary stations were operational. Conbluing these stations with the permanent stactons gives a relatively dense station coverage durlng thls perlod. Earthquakes "caught" by this net might be quite accurately located and then used to callbrate scation corrections for more distant stations as suggested for the blast data in (3) above.

\section{CONCLUSIONS}

A preliminary Interpretation of arrival time data at stations to the north of the Bird Creek blasts suggests that the crustal velocities in the upper 15-20 km can be deacribed by a simple two-layer wodel:

$\begin{array}{ccc}\text { Layer } & \text { Deprh Range (km) } & \text { Velocitg (km/sec) } \\ 1 & 0-1.84 & 5.55 \\ 2 & 1.84-22(?) & 6.22\end{array}$


This model "predicts" the Elrgt arrival at 16 stations ranging in distauce Erom the blast from $11.94 \mathrm{~km}$ to $354.63 \mathrm{~km}$ with standard deviation of 0.29 seconds for the differences between observed and predlcted arrival times.

\section{ACKNOWLEDGEMENTS}

This work was supported from a grant from the Department of Transportation and Public Fac1lities and by Internal funds of the U.S. Geologlcal Survey, the State Division of Geological and Geophysical Surveys, the Geophysical Institute and the Alaska Tsunaml Harniag Center. Sclentiflc personnel - John N. Dav1es, Larry Gedney, Steve Estes, Larry Kent, D1ck Slegrist; Larry Sweet (DIv1sion of Research, DOTPF); Staff, Tsunami Warning Center, Palmer; Robert Page (USGS, Menlo Park, CA). 
TABLE 1

\begin{tabular}{|c|c|c|c|c|c|c|c|c|}
\hline CODE & NAME & $\operatorname{LAT}(N)$ & LONG $(W)$ & $\operatorname{ELEV}(m)$ & $\operatorname{DIST}(\mathrm{km})$ & $\operatorname{CORR}(S)$ & $O P^{\prime} R$ & MAP \\
\hline ETP & Flat Top & 61.1082 & 149.2083 & 427 & 11.94 & -0.09 & $\mathrm{UA}-\mathrm{T}$ & $A-8$ \\
\hline PMS & Arctic Valley & 61.2447 & 149.5606 & 716 & 27.38 & -0.14 & ATWC & \\
\hline PRC & Peters Creek & 61.3902 & 149.4503 & 198 & 44.47 & -0.04 & $\mathrm{UA}-\mathrm{T}$ & $B-7$ \\
\hline EXR & Eklutna Res. & 61.4305 & 149.2583 & 427 & 53.36 & -0.09 & $U A-T$ & $B-6$ \\
\hline SBY & Setrlexs Bay & 61.5155 & 149.6238 & 76 & 56.91 & -0.02 & $U A-T$ & $c-7$ \\
\hline RPZ & Rapunzel & 61.4860 & 149.1102 & 76 & 61.26 & -0.02 & $\mathrm{UA}-\mathrm{T}$ & $B-6$ \\
\hline PMR & Palmer Obs. & 61.5922 & 149.1309 & 100 & 71.33 & -0.02 & ATWC & \\
\hline PWA & Houstoa & 61.6508 & 149.8787 & 137 & 72.78 & -0.03 & ATWC & \\
\hline SSN & Susitna & 61.4638 & 150.7433 & 1297 & 77.00 & -0.26 & USGS & \\
\hline PME & Palmer East & 61.6283 & 149.0211 & 232 & 77.06 & -0.05 & ATWC & \\
\hline KNK & KnIk & 61.4125 & 148.4557 & 595 & 79.07 & -0.12 & USGS & \\
\hline RIZ & Risley & 61.7090 & 149.2233 & 290 & 81.81 & -0.06 & UA-T & $c-6$ \\
\hline MUR & Nurdock & 61.7710 & 149.8035 & 335 & 85.55 & -0.07 & $\mathrm{UA}-\mathrm{T}$ & $D-8$ \\
\hline HTP & Hatcher Pass & 61.7777 & 149.2767 & 917 & 88.43 & -0.18 & $\mathrm{UA}-\mathrm{T}$ & $D-7$ \\
\hline SAW & Sawm11I & 61.8082 & 148.3330 & 740 & 114.02 & -0.15 & USGS & \\
\hline SKN & Skwenta & 61.9803 & 151.5297 & 564 & 146.69 & -0.11 & USGS & \\
\hline SCM & Sheep Mta. & 61.8333 & 147.3277 & 1020 & 154.63 & -0.20 & UA & \\
\hline
\end{tabular}

Distance = vector difference in position between station and ohot point. Correction = travel from zero-elevation datum to station at $5 \mathrm{~km} / \mathrm{s}$

Operator: $\quad$ ATWC $=$ Alaska Tsunaml Warning Center UA * Univerbity of Alaska UA-T = Unlversity of Alaska, temporary station USGS = Untted States Geological Survey

Map: for UA-T scations gives Anchorage 1:63,000 quadrangle designation 
TABLE 2

1982 B1rd Creek Blasts: OrIgin Time, Locacton and Size

\begin{tabular}{|c|c|c|c|c|c|c|c|c|c|}
\hline \multirow[b]{2}{*}{$\underline{z}$} & & & \multicolumn{2}{|c|}{ T1me* (GMT) } & \multicolumn{4}{|c|}{ Location } & \multirow{2}{*}{$\begin{array}{l}\text { Slze } \\
\text { KLB }\end{array}$} \\
\hline & Dat & & HR MN & SEC & N. & Long. & H. & Lat. & \\
\hline 1 & $\begin{array}{r}\text { SEP } \\
\text { (SEP }\end{array}$ & $\begin{array}{l}21 \\
20\end{array}$ & $\begin{array}{l}0417 \\
1917)\end{array}$ & $\begin{array}{l}23.54 \\
\pm .04\end{array}$ & & - & & - & 18.4 \\
\hline 2 & $\begin{array}{r}\text { SEP } \\
\text { (SEP }\end{array}$ & $\begin{array}{l}23 \\
22\end{array}$ & $\begin{array}{l}0413 \\
1913)\end{array}$ & $\begin{array}{r}29.37 \\
\pm .04\end{array}$ & $61^{\circ}$ & $00.30^{\prime}$ & $149^{\circ}$ & $40.40^{\circ}$ & 21.4 \\
\hline 3 & $\begin{array}{r}\text { OCT } \\
\text { OCCT }\end{array}$ & $\begin{array}{l}05 \\
05\end{array}$ & $\begin{array}{l}1902 \\
1002)\end{array}$ & $\begin{array}{l}30.37 \\
\pm .02\end{array}$ & & - & & - & 19.7 \\
\hline 4 & $\begin{array}{l}\text { OCT } \\
\text { OOCT }\end{array}$ & $\begin{array}{l}12 \\
12\end{array}$ & $\begin{array}{l}1845 \\
0945)\end{array}$ & $\begin{array}{r}07.90 \\
\pm 01\end{array}$ & & - & & - & 11.3 \\
\hline 5 & $\begin{array}{r}\text { OCT } \\
\text { COCT }\end{array}$ & $\begin{array}{l}19 \\
19\end{array}$ & $\begin{array}{l}2233 \\
1333)\end{array}$ & $\begin{array}{r}03.13 \\
\pm .01\end{array}$ & $61^{\circ}$ & $00.20^{\prime}$ & $149^{\circ}$ & $39.95^{\prime}$ & 22.7 \\
\hline 6 & $\begin{array}{l}\text { OCT } \\
\text { COCT }\end{array}$ & $\begin{array}{l}26 \\
26\end{array}$ & $\begin{array}{l}1846 \\
0946)\end{array}$ & $\begin{array}{r}10.85 \\
\pm .02\end{array}$ & $61^{\circ}$ & $00.20^{\prime}$ & $149^{\circ}$ & $40.10^{\prime}$ & 6.95 \\
\hline 7 & $\begin{array}{l}\text { OCT } \\
\text { COCT }\end{array}$ & $\begin{array}{l}26 \\
26\end{array}$ & $\begin{array}{l}1912 \\
1012)\end{array}$ & $\begin{array}{l}23.53 \\
\pm .01\end{array}$ & $61^{\circ}$ & $00.20^{1}$ & $149^{\circ}$ & $39.65^{\circ}$ & - \\
\hline
\end{tabular}

*Local time is given in parentheses. 
TABLE 3

\begin{tabular}{|c|c|c|c|c|c|c|c|c|c|}
\hline Explosion & Stac1on & $\begin{array}{l}\text { Dlatance } \\
\quad(\mathrm{km}) \\
\end{array}$ & 1 & $\begin{array}{l}\operatorname{cor} \pi \\
\mathbf{2}\end{array}$ & $\begin{array}{c}\text { ected } \mathrm{T} \\
3\end{array}$ & $\begin{array}{c}\text { ravel } T \\
4\end{array}$ & $\begin{array}{r}\text { Thme日 } \\
5 \\
\end{array}$ & 6 & j \\
\hline $\begin{array}{l}5 \\
6 \\
7\end{array}$ & PTP & 11.94 & $\begin{array}{l}2.18 \\
2.18\end{array}$ & 2.36 & 2.58 & 4.03 & 5.26 & & \\
\hline $\begin{array}{l}5 \\
6 \\
7\end{array}$ & PMS & 27.38 & $\begin{array}{l}4.64 \\
4.71 \\
4.69\end{array}$ & 5.66 & $\begin{array}{l}8.46 \\
8.23\end{array}$ & & & & \\
\hline $\begin{array}{l}5 \\
6 \\
7\end{array}$ & PRC & 44.47 & 7.43 & & & & & & \\
\hline $\begin{array}{l}5 \\
6 \\
7\end{array}$ & EKR & 53.36 & $\begin{array}{l}8.88 \\
8.91 \\
9.88\end{array}$ & 9.21 & 10.58 & & & & \\
\hline $\begin{array}{l}5 \\
6 \\
7\end{array}$ & $58 \mathrm{Y}$ & 56.91 & 9.55 & $\begin{array}{l}10.25 \\
10.30\end{array}$ & & & & & \\
\hline $\begin{array}{l}5 \\
6 \\
7\end{array}$ & 8.22 & 61.26 & $\begin{array}{l}10.15 \\
10.15\end{array}$ & 10.55 & $\begin{array}{l}11.55 \\
11.63 \\
11.64\end{array}$ & 11.98 & 12.98 & & \\
\hline $\begin{array}{l}5 \\
6 \\
7\end{array}$ & PMR & 71.33 & 12.25 & 13.04 & & & & & $23.55(5)$ \\
\hline $\begin{array}{l}5 \\
6 \\
7\end{array}$ & PWA & 72.78 & & $\begin{array}{l}12.91 \\
12.84\end{array}$ & & & & & $23.34(\mathrm{~S})$ \\
\hline $\begin{array}{l}5 \\
6 \\
7\end{array}$ & SSN & 77.00 & 12.51 & 13.34 & & & & & \\
\hline $\begin{array}{l}5 \\
6 \\
7\end{array}$ & PME & 77.06 & 12.65 & $\begin{array}{l}13.92 \\
14.02\end{array}$ & & & & & $24.62(5)$ \\
\hline $\begin{array}{l}5 \\
6 \\
7\end{array}$ & KNK & 79.07 & 12.45 & 13.41 & 14.23 & & & & \\
\hline $\begin{array}{l}5 \\
6 \\
7\end{array}$ & $8 I z$ & 81.81 & $\begin{array}{l}13.79 \\
13.66\end{array}$ & 14.51 & $\begin{array}{l}15.07 \\
14.91\end{array}$ & 15.69 & & & $26.01(5)$ \\
\hline $\begin{array}{l}5 \\
6 \\
7\end{array}$ & MUR & 85.53 & 13.70 & 14.35 & 16.00 & 37.78 & 18.13 & 19.78 & \\
\hline $\begin{array}{l}5 \\
6 \\
7\end{array}$ & UTP & 88.43 & $\begin{array}{l}14.54 \\
14.49\end{array}$ & $\begin{array}{l}15.66 \\
15.67 \\
15.74\end{array}$ & & & & & $27.39(\mathrm{~S})$ \\
\hline $\begin{array}{l}5 \\
6 \\
7\end{array}$ & SAH & 114.02 & 18.02 & 19.12 & 19.62 & & & & \\
\hline $\begin{array}{l}5 \\
6 \\
7\end{array}$ & SKN & 146.69 & & 24.26 & & & & & \\
\hline $\begin{array}{l}5 \\
6 \\
7\end{array}$ & $\mathrm{SCM}$ & 254.63 & 25.17 & 25.77 & & & & & \\
\hline
\end{tabular}


TABLE 4

\begin{tabular}{llcccc} 
& STA & D & $\overline{T T}$ & $\langle$ TT & RES \\
\hline 1 & FTP & 11.94 & 2.18 & 2.22 & -.04 \\
2 & PMS & 27.38 & 4.69 & 4.70 & -.01 \\
3 & PRC & 44.47 & 7.43 & 7.45 & -.02 \\
4 & EXR & 53.36 & 8.89 & 8.88 & +.01 \\
5 & SBY & 56.91 & 9.55 & 9.45 & +.10 \\
6 & RPZ & 61.26 & 10.15 & 10.15 & 0.00 \\
7 & PMR & 71.33 & 12.25 & 11.77 & +.48 \\
8 & PWA & 72.78 & $(12.88) *$ & 12.00 & $(+.88) *$ \\
9 & SSN & 77.00 & 12.51 & 12.68 & -.17 \\
10 & PME & 77.06 & 12.65 & 12.69 & -.04 \\
11 & KNK & 79.07 & 12.45 & 13.01 & -.56 \\
12 & RI2 & 81.81 & 13.73 & 13.45 & +.28 \\
13 & MUR & 85.55 & 13.70 & 14.05 & -.35 \\
14 & HTP & 88.43 & 14.52 & 14.52 & 0.00 \\
15 & SAW & 114.02 & 18.02 & 18.63 & -.61 \\
16 & SKN & 146.69 & 24.26 & 23.88 & +.38 \\
17 & SCM & 154.63 & 25.17 & 25.16 & +.01 \\
\hline & & & & & \\
\hline & & & & &
\end{tabular}

* read as a direct (secondary) arrival and omftced Erom statistics

$v_{1}=5.55 \quad v_{2}=6.22 \quad H_{1}=1.84 \quad \mathrm{~N}=16$

Mean $=-0.03$

$\mathrm{SDEV}=0.29$

+ EXT $=0.48$

$-E X T=0.61$

$\langle T T\rangle=\frac{\sqrt[2]{D_{1}^{2}+u_{1}^{2}}}{v_{1}}+\frac{D-2 D_{1}}{v_{2}}$

where $D_{1}=\mathrm{H}_{1} \tan \theta_{1}$

and $\sin \theta_{1}=\frac{v_{1}}{v_{2}}$

RES $\equiv \overline{T T}-\langle T T\rangle$

$\overline{\mathrm{TT}} \equiv$ mean of the corrected travel times for first arrival. 
Figure 1. Location map for selsmic gtations used to record the Bird Creek blasts. The solld trlangles mark the locationg of permanent gtations, while the open trlangles mark the locations of temporary stations established for the present study. Not shown on the map are the locationg of other permanent stations (generally to the south of the blast site) nor those of the temporary stations established by the USGS along the roads south from the blast site to Seward.

Figure 2. Time-distance plot for the travel times of selsulc waves from the Blrd Creek blasts to the varlous recording statlons. The corrected travel time is plotted against distance to the regpective seisalc station. The corrected travel time is the arrival time minus the orlgin time (of the blast) minus the elevation correction. The symbols are as follows: vertical bar a single arrival, triangle $\Rightarrow$ double arrival or single first arrival, circle $=$ eriple arrival or double first arrival, gquare = triple first artival. The data represented by solld symbols were used to calculate the slope and intercept of the line of the refracted arrivals. The data represented by open symbols were used to calculate the slope of the line of the direct arrivals; tils line, by definltion, is constrained to go through the origln. 


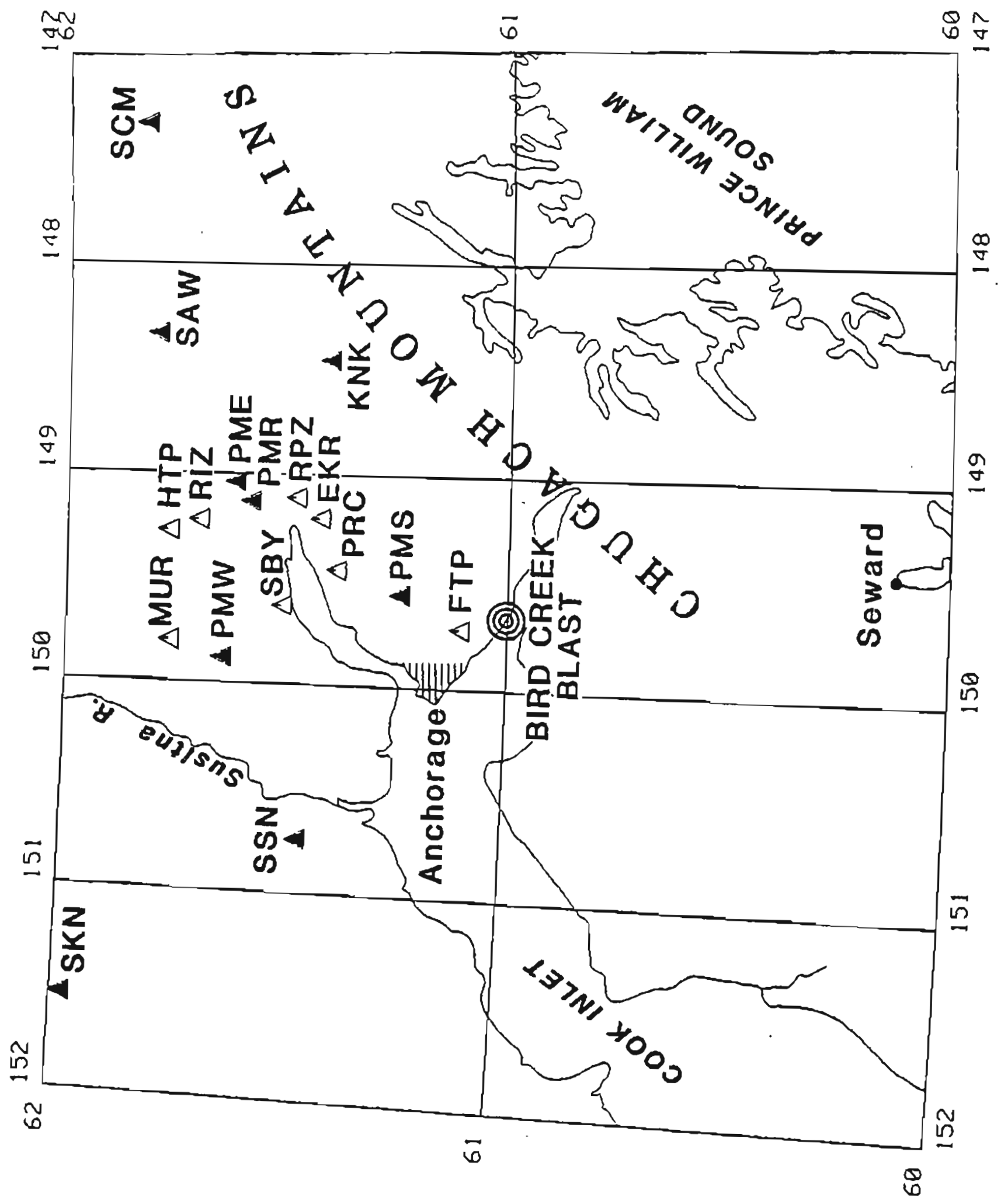

Figure 1 


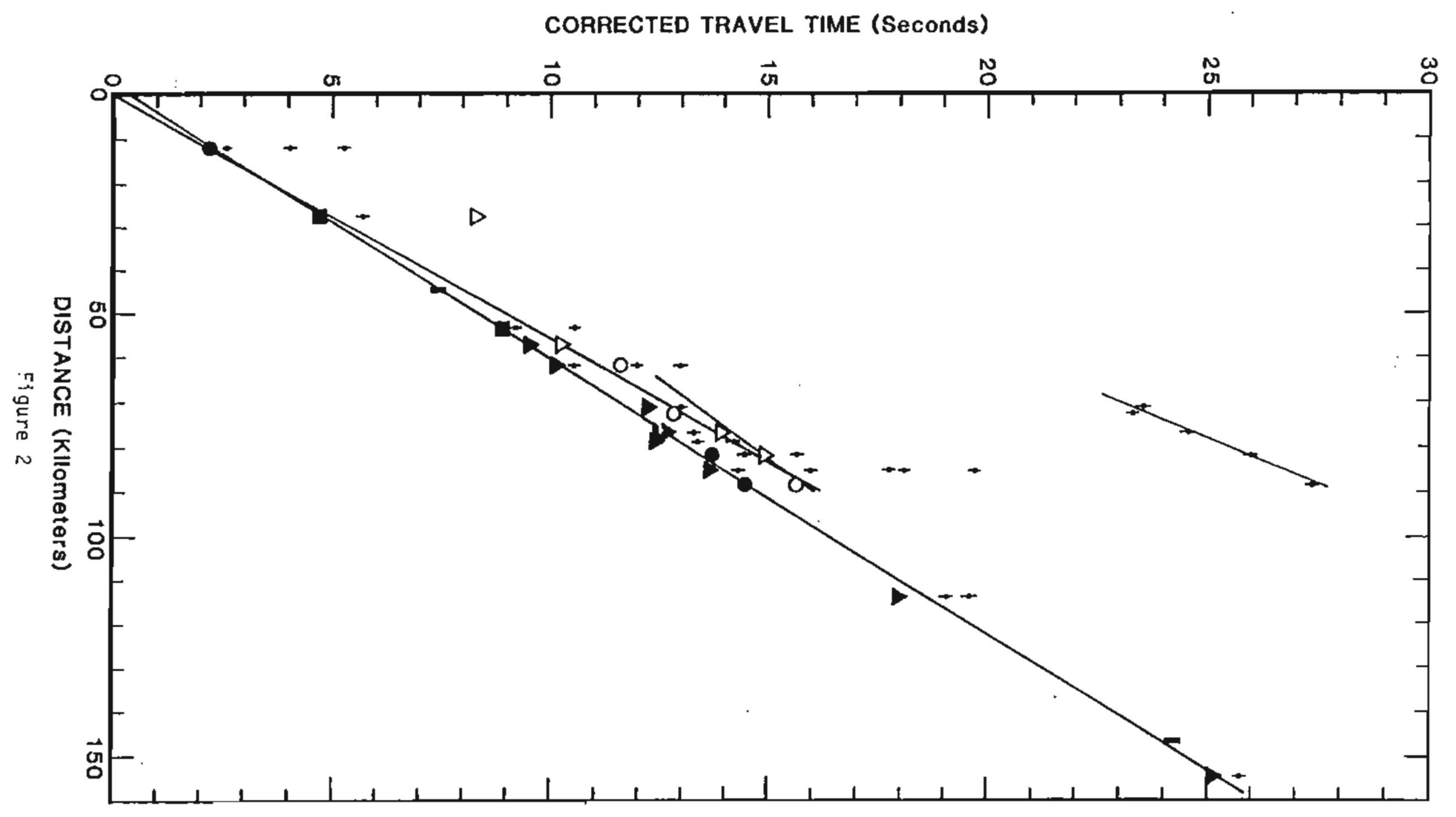

